\title{
THE CRIME INVESTIGATION ACTIVITY OF THE BORDER POLICE T. Giurea
}

\author{
Tiberiu Giurea \\ PhD Candidate at Police Academy \\ *Correspondence: Tiberiu Giurea, Agora University of Oradea, 8 Piaţa Tineretului \\ St., Oradea, Romania \\ E-mail:tiberiugiurea@yahoo.com
}

\begin{abstract}
Following analysis, it has been concluded that in order for the criminal prosecution activity to become more effective, legislative amendments are required that would allow the activity of border police officers to be carried out under the exclusive control of the prosecutors.

Ministry representatives claim that the effectiveness of the judicial police is diminished because of their double subordination and that the proposed legislative amendments allow for a clear delineation between judicial and administrative functions and guarantee the status of the police officers in the border police, whose professional career will depend exclusively on how their activity is evaluated by the magistrate overseeing the prosecution.
\end{abstract}

Keywords: investigation, crime, judicial police, police officer, criminal prosecution, information.

\section{Introduction}

Taking as a starting point the perception of the phenomenon's development in its essence, of course, all rules and relationships that govern this complex activity have room for improvement in order to adapt themselves to the current criminal trends in the field.

This research paper is primarily intended as an accumulation of knowledge on European realities in the field, and secondly as an identification of international and national rules, being aimed at identifying the gaps and issuing concrete proposals for the improvement of the efficiency of the border police activity, proposals for the improvement of the legal, institutional and procedural and action-taking framework, all of these on an international and European level.

The border police, whose existence is necessary in all countries, cannot, however, ignore or neglect democracy. Indeed, the organization and operation of the police bodies has been and still is one of the capital issues on which the democratic or totalitarian nature of a State depends.

However ideally organized the border police, their activity depends to a large extent on the professional training and honesty of officers. It is a truth rooted in the development of law and the administration science that public services are not worth anything if the officials are not skilled, well-trained and loyal to their office. 
In connection with the border police, which are the main internal order authority within a State, there has always been confusion and a hateful mentality. Even today there is the opinion that the police are meant to protect the political supporters of the government and to persecute their adversaries, which is an outdated concept. The border police must ensure the satisfaction of all citizens and normal progress towards democracy in Romania, at present, and even with greater force in the future.

Freed from pressures or political influence, the border police must only obey the law and truth, while enjoying greater dignity.

It is the status of the Romanian police officer (rights, obligations and responsibilities) which determines whether we live or will live in a state of disorder or tranquillity. In other words, by the way in which the police are organized and operate, one can determine whether our society is full of virtue or loaded with vices or bad habits.

In the increasingly dynamic pace of life today, more and more dominated by the agitation of national, social, political and economic unrest, and on the other hand, the resurgence of crimes of all kinds, police tasks are augmented and become increasingly difficult. In all their undertakings for the exercise of their profession or in social life, police officers should know that there is no other judge for them but the law and the community they serve.

According to the widely accepted international norms, the police must provide a guarantee of the rights and freedoms of individuals, their property, public order and the institutions established by the Constitution.

In exercising their duties, the police are to carry out their missions in compliance with the Universal Declaration of the Rights of Man and the Citizen. Therefore, they are available to any natural or legal person under the conditions prescribed by law.

Border Police are organized hierarchically and are under the political authority of the Minister of Internal Affairs and the administrative authority of the chief of the General Inspectorate of Romanian Border Police.

Placed in the public service, police officers must have an exemplary conduct, show absolute respect for the individual, regardless of their nationality or origin, social condition or political, religious or philosophical convictions.

The police officer is obliged, even outside office hours, to intervene on his/her own initiative in order to help any person in danger, to prevent or stop any act likely to disturb public order, to protect the individual, the community and property.

Given the network of professional relationships, the Public Ministry has proposed several variants for taking over the judicial police, such as administrative control, the relocation of police officers within the Prosecutors' Offices or passing over the duties regarding the police officers' professional career to the competence of this institution.

Following analysis, it has been concluded that in order for the criminal prosecution activity to become more effective, legislative amendments are required that would allow the activity of border police officers to be carried out under the exclusive control of the prosecutors.

Ministry representatives claim that the effectiveness of the judicial police is diminished because of their double subordination and that the proposed legislative amendments allow for a clear delineation between judicial and administrative functions and guarantee the status of the police officers in the border police, whose professional 
career will depend exclusively on how their activity is evaluated by the magistrate overseeing the prosecution.

Mainly, the observations of the Prosecutor's Office attached to the High Court of Cassation and Justice are based on the fact that it is essential to differentiate between the police structures with administrative duties and the judicial police, the latter structure having the task to find and track any criminal offence, in compliance with the rules of criminal procedure, and to enforce the measures ordered by prosecutors ${ }^{1}$.

One solution would be to relocate police officers to the prosecutor's offices within the Public Ministry. The solution is similar to that currently regulated at the National Anticorruption Directorate, which has proven effective, on condition that coordinating prosecutors annually fill in assessment sheets concerning the judicial police officers, sheets that should be taken into consideration in the final assessment carried out by the professional chiefs.

Another solution could be that these workers of the judicial police should keep their position in the specialized structures of the Ministry of Administration and Interior, but the professional assessment of workers in the judicial police should ONLY be within the competence of prosecutors, who exercise the coordination, control and conduct of criminal investigation activities.

All the issues mentioned above must also be considered in light of the new European context, so that judicial cooperation in criminal matters has become, since the entry into force of the Treaty of Maastricht, in November 1993, a matter of high priority for all Member States of the European Union and the Council itself. Cooperation between Member States in the field of justice and internal affairs is conducted in the socalled third pillar of the European Union. The idea of creating an area of freedom, security and justice in Europe becomes more of a reality every day in the European Union and the Council has adopted in recent years a significant number of legal instruments, which either have already been implemented in the Member States or their implementation in national legislation is in progress. Many new projects are also under preparation in the various working groups of the Council. The entry into force of the Amsterdam Treaty on $1^{\text {st }}$ May 1999 has strengthened this development. In 1997 the European Council adopted an action plan in order to combat organized crime, which was prepared by a high-level group of experts from the Member States. Several of the recommendations of this expert group formed the basis of the action plan to improve the standards of cooperation between judicial authorities in criminal matters. On the basis of this action plan, the Council adopted on $29^{\text {th }}$ June 1998 a Joint Action to create a European Judicial Network. This network was officially inaugurated on $25^{\text {th }}$ September 1998 by the Austrian Minister of Justice, who held the European Union Council Presidency. They have regular working meetings and take an active role as intermediaries, their precise task being to facilitate judicial cooperation between Member States and provide legal and practical information on mutual legal assistance to those interested in this field and the general improvement of judicial cooperation coordination between Member States.

The scientific novelty and originality of the thesis consists in the formulation of certain theoretical and practical conclusions and the submittance of proposals with a

\footnotetext{
${ }^{1}$ Mateaş Florian - Poliţia de Frontieră Română - Evoluţie şi perspective” (Romanian Border Police - Evolution and Perspectives), Editura (Publishing House) Pro Universitaria, Bucureşti, 2007, pp.67
} 
view to the future law (de lege ferenda), logically resulting from the investigations carried out, contributing to the completion of the doctrine in the matters concerned, the improvement of the legislation in force, logically harmonized with already existing national and international regulations.

The theoretical importance and applicative value of the work is determined by the possibility of using the proposals. For Romania, which is currently still in a process of reform, all the issues in the study presented are extremely useful in substantiating and directing general and sectoral strategies designed to lead to a legal regulation of the judicial police compatible with those of the European Union countries.

\section{Management of criminal investigation activities within the judicial police}

\section{Working Methods and Means Information Gathering}

Information is the material of any description, including those derived from observation, stakeout, reports, rumors and other sources. The information itself may be true or false, accurate or inaccurate, confirmed or unconfirmed, relevant or irrelevant. Although the information process requires that information should be stored, organized and reaccessed, the production of valuable information involves much more.

Valuable information is the product resulting from the collection, evaluation and interpretation of data. Thus, valuable information can be seen as information to which something was added. This something added is the result of analysis - an explanation of what the information means.

Valuable information can be general or specialized. Information of general value focuses on a wide range of criminal activities, typical for small police units or areas of competence. The information of special value focuses on a particular type of criminal activity, such as drug trafficking, industrial espionage or organized crime.

Value-added information has both operational and strategic applicability. The information of tactical value is directed at the objectives of the law enforcement institution in the short term, with immediate impact, consisting of arrest, sequestration or capture. The information of strategic value is related to larger issues and targets, in the longer term, such as the identification of major criminals or criminal groups, projections of the development of certain types of criminal activity and prioritization in the law enforcement activity².

For a better enforcement in the field of the police, it is necessary to find out what information and its analysis mean in practical and theoretical terms. They may seem simple activities, and even today there are disputes as to what these terms in the field in which we operate mean.

The concept of gathering and using information to support decision-making, in a structured form, is not new. In order to obtain advantage over an opponent, it is necessary to process the newest and most representative pieces of information, inter alia, regarding his/her intentions and capabilities. This rule applies in all fields, be it politics, business, military strategies or information of a criminal nature.

\footnotetext{
${ }^{2}$ Mateaş Florian, Popescu Cristian, Matei Cristian - ,,Investigarea criminalităţii transfrontaliere” (Investigation border crime) - Editura (Publishing House) M.I.R.A., Bucureşti, 2007, pp. 72.
} 


\section{T. Giurea}

It is a process that has been, is and will be in constant development and evolution, in response to changing socio-cultural, technological factors, organizational needs and new/increased analytical skills.

\section{Analysis of information of a criminal nature}

For most people, including investigators, the term evokes images of collation systems used in order to store and reaccess information that we collect about crimes and criminals. As the volume and variety of the information that we have been collecting has increased, we have gradually introduced more complex systems to assist us in storing and revisiting it. In this limited context, the introduction of information technology has been a notable success. The use of computers to store and revisit criminal information is now almost a second nature for operational investigators and there is no doubt that, without this tool, as a unit, we would simply not be able to handle the task of recording and collation criminal information.

\section{SWOT Analysis}

In the modern age, anti-crime strategies also resort to forms of analysis-synthesis of the results used in areas other than public order. Studying the entities involved in the fight against crime, we highlight their polarization into two categories: some that gain considerable successes and others that are struggling hard to achieve the desired results or have modest achievements.

\section{Task-force in the current context}

TASK-FORCE is a working group created in order to work for the achievement of the same stated goal, consisting of representatives of several entities, which do not necessarily belong to the same area of activity.

Originally introduced by the Royal Navy, the term has now become of "general use" and is part of the NATO-type work standards.

The concept initially came into widespread use in the Royal Navy around year 1941, as a way to increase operational flexibility.

At that time the need for ships of different divisions and squadrons from different countries to collaborate without being united under a single command imposed cooperation in the form of a working group composed of the commanders of various military units, in pursuit of the same purpose.

Many non-military organizations establish at present "working groups" or working groups for temporary activities which, in the past, were carried out by the socalled ad hoc committees.

\section{The undercover investigator}

The institution of the undercover investigator was first introduced in Romanian legislation by Article 21 of $\mathrm{Law}^{3}$ no. 143 of $26^{\text {th }}$ July 2000 on combating the trafficking and use of illegal drugs and Government Emergency Ordinance ${ }^{4}$ no. 43 of $4^{\text {th }}$ April 2002 on the National Anticorruption Prosecutor's Office.

\footnotetext{
${ }^{3}$ Published in the OFFICIAL JOURNAL no. 362 of $3^{\text {rd }}$ August 2000, as amended and supplemented by: LAW no. 169 of $10^{\text {th }}$ April 2002; LAW no. 39 of $21^{\text {st }}$ January 2003; LAW no. 522 of $24^{\text {th }}$ November 2004.

${ }^{4}$ Published in the OFFICIAL JOURNAL no. 244 of $11^{\text {th }}$ April 2002, as amended and supplemented by: LAW no. 503 of $11^{\text {th }}$ July 2002; LAW no. 161 of 19 th April 2003; EMERGENCY ORDINANCE no. 102 of $24^{\text {th }}$ October 2003; LAW no. 26 of $5^{\text {th }}$ March 2004; EMERGENCY ORDINANCE no. 24 of $21^{\text {st }}$ April 2004; EMERGENCY ORDINANCE no. 103 of $16^{\text {th }}$ November 2004; LAW no. 601 of $16^{\text {th }}$ December 2004; LAW no. 247 of $19^{\text {th }}$ July 2005; EMERGENCY ORDINANCE no.120 of $1^{\text {st }}$ September 2005; EMERGENCY ORDINANCE no. 134 of $29^{\text {th }}$ September 2005; LAW no. 383 of $16^{\text {th }}$ December 2005;
} 


\section{Covert actions}

A covert action consists in influencing conditions and conduct in forms that cannot be ascribed to the entity under whose auspices it is carried out. Convert actions and the counterintelligence service seek to manipulate and control opponents. One of the main differences between them is that a covert action is usually conducted by players outside the intelligence sphere, whereas counterintelligence concerns staff of the intelligence services of opponents and political leaders. Covert action seeks to influence open values, institutions and instruments or is aimed at state and non-state players.

\section{Body search, house search}

In order to ascertain the existence of the facts and factual circumstances which form the subject of criminal cases, as well as the guilt of the perpetrators, judicial bodies carry out a complex evidentiary activity.

Judicial search is part of the investigation procedures used in the management of evidence and material means of evidence by judicial bodies. As an evidentiary procedure, the search is frequently performed in judicial practice, in order to search and seize objects that contain or bear the traces of the crimes committed, material evidence or documents known or unknown by the judicial bodies and which may serve to finding the truth.

In most criminal cases, judicial bodies resort to this evidentiary procedure in order to discover objects, goods, documents and other valuables related to the cases investigated, by means of which they can prove the criminal activity and, therefore, the defendant's guilt.

The effectiveness of the search largely depends on how this activity is planned, prepared and carried out by the judicial bodies, as well as finding the right moment to perform it.

The search must be conducted in strict accordance with the legal provisions, the judicial bodies having the obligation to respect the constitutional rights of the persons investigated and not to obstruct or restrict these rights except to the extent that is absolutely necessary for solving the criminal case.

From the time of perpetration of a criminal offence until the carrying out of the judicial search, generally, a variable period of time passes, which often leads to missing the best operational moment for carrying out this activity. Moreover, within that time period, the evidence sought by the judicial bodies may disappear or be hidden. There is also the possibility that the perpetrator might be informed through other individuals involved in the criminal proceedings (witnesses, accomplices, aggrieved party, etc.) about the activities of the judiciary, which might lead him to concealing, disposing of or destroying the means of evidence necessary in order to solve the case.

\section{The concept of judicial search}

The search can help solve criminal cases through the objects and documents it may uncover and which may have relevance in elucidating some aspects of these cases. The importance of judicial search as an investigative procedure was underlined in the specialty literature which mentions that this activity provides indispensable evidence, sometimes the only pieces of evidence, necessary in order to solve criminal cases.

LAW no. 35 of $1^{\text {st }}$ March 2006; LAW no. 54 of $9^{\text {th }}$ March 2006; EMERGENCY ORDINANCE no. 27 of $29^{\text {th }}$ March 2006. 
Some authors considered that no other activity implies involvement in the most intimate aspects of an individual's life, their rights over real estate property and land, as does the search.

The word "search" (Rom.: percheziție) comes from the Latin word "perquiro", which means "to seek", "to look carefully everywhere", designating a particularly important activity within the preliminary criminal investigation. According to Professor V. Manzini, "searches are material researches, that may be conducted through coercion, allowed as exceptions from the normal safeguards of individual liberty, in order to ensure in the process items which might serve as evidence or to arrest the defendant or another person suspected of the crime or fugitive".

According to the definition contained in the Explanatory Dictionary of the Romanian Language, the search is a research done by the prosecution bodies or by the prosecutor against a person (suspected of a crime) or in that person's dwelling, in order to find and collect material evidence of the crime or identify the perpetrator ${ }^{5}$.

According to another opinion, house search consists in the inspection and the research of the dwellings of the detainee, his accomplices, his hosts and any other individuals who may hold evidence of guilt.

\section{The legal regulation of the judicial search procedure}

The legal regulation of search has undergone significant alterations since year 1990, materialized through the adoption of new regulatory acts in this field: Decree -Law no. 12/1990, Law no. 32/1990, Law no. 104/1992, Law no.141/1996, Law no. 281/2003, Law no. 356/2006 and Government Emergency Ordinance no. 60/2006. These changes were intended to harmonize the provisions of the Criminal Procedure Code with the principles, recommendations and regulations contained in the international criminal justice documents and to transpose into national legislation the provisions of the Convention for the Protection of Human Rights and Fundamental Freedoms and the jurisprudence of the European Court of Human Rights. The change of substance occurred as a result of these changes consisted in the fact that the judge received exclusive jurisdiction to authorize house search, both in the criminal investigation stage and the trial stage.

According to the previous regulation, the search could also be ordered by the prosecutor during the criminal prosecution stage, and in the case of a flagrant offence or if the person searched consented in writing to the search, no authorization was necessary.

\section{Institutions with an indirect role in criminal prosecution}

\section{The Romanian Intelligence Service ${ }^{6}$}

The Romanian Intelligence Service (SRI) is the national authority in preventing and combating terrorism, as well as in the field of armed attendants aboard aircrafts. It is a complex responsibility that requires concerted actions and measures: information gathering, multisource analysis, monitoring, anti/counter-terrorist intervention, as well as internal cooperation - with public authorities and institutions belonging to the National

\footnotetext{
${ }^{5}$ Constantin Aioniţoaie, Ion-Eugen Sandu (coordinators) et al. - Tratat de tactică criminalistică (Treatise of Forensic Tactics) (2 $2^{\text {nd }}$ edition revised and amended), Editura Carpaţi (Publishing House), Craiova, 1992, p. 207.

${ }^{6}$ www.sn.ro
} 
System for Preventing and Combating Terrorism (SNPCT) - and international cooperation.

\section{The Foreign Intelligence Service ${ }^{7}$}

The Foreign Intelligence Service (SIE) is the state institution specialized in foreign intelligence regarding national security, Romania's defence and its interests.

\section{The Department of Intelligence and Internal Protection ${ }^{8}$}

The Department of Intelligence and Internal Protection is the specialized structure of the Ministry of Internal Affairs which conducts intelligence and internal protection, in order to ensure public order, to prevent and combat threats to national security regarding the missions, the personnel and classified information within the ministry.

\section{The General Anticorruption Directorate ${ }^{9}$}

The General Anticorruption Directorate was established under Law no.161/2005 and is the structure of the Ministry of Internal Affairs specialized in preventing and fighting staff corruption within the ministry.

\section{The National Anticorruption Directorate ${ }^{10}$}

The National Anticorruption Directorate (DNA) is a prosecuting structure specialized in combating high and medium-level corruption. It was created as a necessary tool in detecting, investigating and bringing to court medium and high-level corruption cases. Through its work, it contributes to reducing corruption, in support of a democratic society that is closer to European values. The DNA, as a structure with clearly defined powers to combat high and medium-level corruption, was created after a model adopted by several European countries - Spain, Norway, Belgium, Croatia. Why was it necessary to create a specialized prosecuting structure for the sole purpose of fighting high and medium-level corruption, as long as petty corruption, or rather, everyday corruption, "counter corruption" is a phenomenon with a stronger impact on the citizens? The answer is the following: corruption at all levels is fueled when corrupt people who have certain levers of power have the feeling that they are above the law, that they are intangible and that society does not have sufficient effective means to prove their criminal activities and hold them accountable. In order to efficiently combat such type of criminality, which is part of the "white collar criminality", it is necessary to have a specialized, independent institution, endowed with the appropriate resources. The concrete results achieved by the specialized institution in combating high-level corruption are meant to discourage corruption at all levels. DNA is an independent entity in its relations with the courts, with the prosecutor's offices attached to these courts, as well as in its relations with the other public authorities.

The Directorate for Investigating Organized Crime and Terrorism ${ }^{11}$

By Law no. 508/2004, the Directorate for Investigating Organized Crime and Terrorism (DIICOT) was established, as a structure specialized in the fight against organized crime and terrorism of the Prosecutor's Office attached to the High Court of Cassation and Justice, through the reorganization of the Department for Combating Organized Crime and Drugs and its territorial structure. The reason for setting up this

\footnotetext{
${ }^{7}$ www.sie.ro

${ }^{8}$ www.dgipi.ro

${ }^{9}$ www.mai-dga.ro

${ }^{10}$ www.pna.ro

${ }^{11}$ www.diicot.ro
} 
structure was the formation of an elite corps of prosecutors specializing in investigating crimes of extreme gravity.

\section{The Special Operations Directorate ${ }^{12}$}

The Special Operations Directorate is a unit of information, tactical-operational and technical-operational specialized support serving the structures of the Ministry of Internal Affairs, the Romanian Police General Inspectorate and the Public Ministry which seek professional support in handling complex matters in operational situations requiring urgent action or presenting a high degree of risk.

At territorial level, the directorate comprises 14 regional services, distributed according to the Courts of Appeal principle, and 26 territorial departments in the remaining counties of the country.

\section{The Defence Intelligence General Directorate}

The Defence Intelligence General Directorate ensures the procurement, processing, checking, storage and recovery of information and data on risk factors and internal and external, military and non-military, threats, that may affect national security in the military field, it coordinates the implementation of counter-intelligence measures and cooperation with national and intelligence services/departmental structures, as well as with those of the Member States, of international alliances, coalitions and organizations to which Romania is part and it ensures the security of national, NATO and the European Union classified information at the level of the Ministry of Defence.

\section{The National Office for Witness Protection ${ }^{13}$}

The National Office for Witness Protection is an operational unit of the Ministry of Internal Affairs, it reports directly to the Romanian Police General Inspectorate, having general territorial jurisdiction.

\section{The Interpol National Bureau ${ }^{14}$}

The International Criminal Police Organization (O.I.P.C./ICPO) is an intergovernmental institution which provides mutual assistance between the police forces of member states in order to prevent and suppress common law crime; it does not intervene in political, military, religious or racial matters; it respects the sovereignty and independence of each country; it ensures the exchange of police-related information at international level; it identifies wanted criminals with international warrants to their names; it coordinates theactivities of surveillance and catching of international criminals; it informs units specialized in matters related to the theft or loss of foreign identity documents, international drug trafficking, money forgery, auto theft and art theft, etc., in order for them to take operational measures.

\section{Conclusion}

Upon request, it requests the information necessary in order to solve certain criminal cases. Interpol National Central Bureaus make up the national fulcrum for international police cooperation. Created in each Member State of the ICPOINTERPOL, National Central Bureaus are made up of national officials who always act within the legal framework provided by the legislation of their country. Their role is to

\footnotetext{
12 www.politiaromana.ro/operaţiuni-speciale

${ }^{13}$ WwW.politiaromana.ro/oficiul-national-pentru -protectia-martotilor.htl

${ }^{14}$ www.mira.gov.ro/biroul-national -INTERPOL.htl
} 
overcome the obstacles that international cooperation faces because of the difference in structure between national police, language barriers and differences in the legal systems of member countries.

\section{Bibliography:}

1. Bălan George - Combaterea traficului şi consumului de droguri prin noile măsuri prevăzute în Legea nr. 143/2000 (Combating Drug Trafficking and Consumption through the New Measures Provided by Law no. 143/2000), in Revista de criminologie, criminalistică şi de penalogie (The Journal of Criminology, Forensic Science and Penology), issue no. 7/2000;

2. Bălan George - Rolul Ministerului Public în luarea de măsuri administrative faţă de străinii care desfăşoară activităţi de natură să pună în pericol siguranţa naţională (The Role of the Public Ministry in Taking Administrative Measures against Aliens Who Carry Out Activities Which May Jeopardize National Security), in Pro Lege, issue no. 2/2005;

3. Bălan George - Noile tendinţe mondiale în acţiunea politicilor de apărare a securităţii statelor şi de combatere a terorismului (New World Trends in the Action of the State Security and Combating Terrorism Policies), in Doctrină şi Jurisprudenţă (Doctrine and Jurisprudence), issue no. 3/2005;

4. Botoş Ilie - Mecanismele informative de control şi documentare a activităţii circumscrise terorismului (Informative Mechanisms of Control and Documentation of Activities Related to Terrorism), in Pro Lege, issue no. 4/2004;

5. Călinoiu Constantin - Implicaţii politice şi constituţionale ale extinderii Uniunii Europene (Political and Constitutional Implications of EU Enlargement), in Pro Patria Lex, Academia de Poliţie „Alexandru Ioan Cuza” (Police Academy "Alexandru Ioan Cuza"), issue no. 5/2004;

6. Cristescu Doru Ioan - Tehnici de obţinere a materialelor de comparaţie necesare unor constatări şi expertize dispuse cu prilejul investigării infracţiunilor contra securităţii naţionale şi de terorism (Techniques for Obtaining the Comparison Materials Necessary for Findings and Expertise Ordered During the Investigation of Crimes Against National Security and Terrorism), in Revista de criminologie, de criminalistică şi penalogie (The Journal of Criminology, Forensic Science and Penology), issue no. 4/2004;

7. Herghelescu Liviu - Despre posibilitatea instanţei de judecată de a cunoaşte identitatea reală a investigatorului sub acoperire (On the Possibility of the Law Court to Know the Real Identity of the Undercover Investigator), in Dreptul (Law), issue no. $5 / 2005$;

8. Hărăştanu Angela, Predescu Ovidiu - Investigatorul sub acoperire. Rolul instanţelor de judecată privind activitatea acestuia (The Undercover Investigator. The Role of the Law Court with Regard to His Work, in Dreptul (Law), issue no. 5/2004;

9. Gorgăneanu I. Gheorghe - Noi reglementări privind perfecţionarea legislaţiei procesuale penale (New Regulations on the Improvement of Criminal Procedural Legislation), in Revista de drept penal (Criminal Law Journal), issue no. 2/1996, p. 34 ; 


\section{T. Giurea}

10. Gâdea Cornel - Criminalitatea informatică greu de combătut (Difficult-to-Fight Cybercrime), in Revistă de Criminalistică (Forensic Science Journal), issue no. 5/2000;

11. Kovesi Laura Codruţa - Accesul şi supravegherea sistemelor de telecomunicaţii sau informatice (Access and Surveillance of Telecommunications or Computer Systems), in Pro Lege, issue no. 2/2003;

12. Lascu Laurenţiu - Investigatorul acoperit (The Undercover Investigator), in Revista de drept penal (Criminal Law Journal), issue no. 3/2002;

13. Mateaş Florian - Poliţia de Frontieră Română - Evoluţie şi perspective", (Romanian Border Police - Evolution and Perspectives) Editura (Publishing House) Pro Universitaria, Bucureşti, 2007

14. Mateaş Florian, Popescu Cristian, Matei Cristian - „Investigarea criminalităţii transfrontaliere" (Investigation border crime) - Editura (Publishing House) M.I.R.A., Bucureşti, 2007.

15. Mateuţ Gheorghe - În legătură cu noua reglementare privind înregistrările audio sau video în probaţiunea penală (On the New Regulation regarding Audio or Video Recordings in Criminal Evidence Production), in Dreptul (Law), issue no. 8/1997; 14. Manda Cristina Măria - Globalizarea şi statul naţional (Globalization and the National State), in Revista...

16. Andreescu Anghel, Toma Gheorghe - Conflictele sfârşitului de mileniu (Conflicts at the End of the Millennium), Editura Timpolis (Publishing House), Timişoara, 1998;

17. Antoniu George - Noul cod penal. Codul penal anterior. Studiu comparativ (New Criminal Code. Previous Criminal Code. A Comparative Study), Editura AII Beck (Publishing House), Bucharest, 2004;

18. Banciu Dan, Rădulescu M. Sorin - Corupţia şi crima organizată în România (Corruption and Organized Crime in Romania), Editura Continent XXI (Publishing House), 1994;

19. Bannelier Karine, Christakis Theodoree, Carten Oliver, Delcourt Barbara - Le droit international face au terrorisme (International Law against Terrorism), Cedin, Paris, Cahier internationaux nr. 17, Pedone Publishing House, 2002;

20. Bădescu Mihai - Drept constituţional şi instituţii politice (Constitutional Law and Political Institutions), Editura Lumina Lex (Publishing House), Bucharest, 2001;

21. Bârsan Gheorghe - Securitatea Publică (Public Security), Editura M.A.I. (Ministry of Internal Affairs Publishing House), Bucharest, 2005;

22. Berger Vincent - Jurisprudenţa Curţii Europene a Drepturilor Omului (Jurisprudence of the European Court of Human Rights), 4th edition (transl. Ionel Olteanu, Comei Atanasiu), Institutul Român pentru Drepturile Omului (Romanian Institute for Human Rights), Bucharest, 1988;

23. Bobocescu Vasile - Istoria Poliţiei Române (History of the Romanian Police), Editura Ministerului de Interne (Ministry of Interior Publishing House), Bucharest, 2000;

24. Bulai Constantin - Drept penal. Parte generală (Criminal Law. The General Part), vol. III - Răspunderea penală. Sancţiunile în dreptul penal (Criminal Liability. The Penalties under Criminal Law), Bucharest, 1982;

25. Carp Gheorghe - Terorismul internaţional (International Terrorism), Editura M.A.I. (Ministry of Internal Affairs Publishing House), Bucharest, 2005; 
26. Câmpeanu Paul - Legea şi legalitatea în România (Law and Legality in Romania), Editura Antet (Publishing House), Bucharest, 2005;

27. Cochinescu Nicolae - Totul despre Ministerul Public (All about the Public Ministry), Editura Lumina Lex (Publishing House), Bucharest, 2000;

28. Diaconescu Gheorghe, Duvac Constantin - Drept penal. Parte specială (Criminal Law. The Special Part)

29. Noul Cod penal (New Criminal Code), vol. I, Spiru Haret University, Editura Fundaţiei (Publishing House). 